\title{
ANALISIS KEMAMPUAN KOMUNIKASI KEPALA SEKOLAH TERHADAP PENINGKATAN KINERJA GURU
}

\author{
Wakini' $^{1}$, Efrita Yanti², Demina ${ }^{3}$, Sufyarma Marsidin ${ }^{4}$ \\ 1,2,3,4 Institut Agama Islam Negeri Batusangkar \\ email: wakinikikin759@gmail.com
}

\begin{abstract}
Communication skills are important to achieve the goals that have been set. Without good communication skills, any message conveyed will not be successfully captured and understood by anyone. Communication is a process of delivering information from the communicator to the communicant to achieve certain goals. This study aims to analyze the effect of the principal's communication skills in improving the performance of school teachers. This research is a qualitative research with descriptive analysis technique with library research where this research tries to describe the existing phenomena, which took place now or in the past. From the results of the research that has been carried out by the researchers above, the researchers conclude that the principal must have skills 1) a principal must have the skills to communicate both orally and in writing. 2) The principal must manage vertical, horizontal and judgmental communication with the school in carrying out task coordination, namely by listening, facilitating, asking questions, using considerations, and directing with the teacher council or school committee so that the school achieves the goals that have been set. So that all these competencies can affect the improvement of teacher performance in schools to achieve educational and learning goals.
\end{abstract}

Keywords: communication skills, school teachers, teacher performance.

\begin{abstract}
Abstrak : Keterampilan berkomunikasi adalah hal yang penting untuk mencapai tujuan yang sudah ditetapkan. Tanpa adanya keterampilan berkomunikasi dengan baik apapun pesan yang disampaikan tidak akan berhasil ditangkap dan dipahami oleh siapapun komunikasi merupakan proses penyampaian informasi dari komunikator kepada komunikan untuk mencapai tujuan tertentu. Penelitian ini bertujuan untuk menganalisis pengaruh kemampuan komunikasi kepala sekolah dalam meningkat kinerja guru sekolah. Penelitian ini merupakan penelitian kualitatif dengan teknik analisis deskriptif dengan kajian kepustakaan (library research) dimana penelitian ini berusaha menggambarkan fenomena-fenomena yang ada, yang berlangsung saat ini atau saat yang lampau. Dari hasil penelitian yang sudah dilakukan oleh peneliti diatas maka peneliti menyimpulkan bahwa kepala sekolah harus memiliki keterampilan 1) seorang kepala sekolah harus memiliki keahlian melakukan komunikasi baik secara lisan maupun tulisan. 2) Kepala sekolah harus mengelola komunikasi vertical, horosontal dan diamental kepada sekolah dalam melaksanakan koordinasi tugas, yaitu dengan mendengarkan, memfasilitasi, menanya, menggunakan pertimbangam, dan mengarahkan dengan dewan guru atau komite sekolah supaya sekolah mencapai tujuan yang telah ditetapkan. Sehingga semua kompetensi tersebut dapat mempengaruhi peningkatan kinerja guru di sekolah untuk mencapai tujuan pendidikan dan pembelajaran.
\end{abstract}

Kata Kunci: kemampuan komunikasi, guru sekolah, kinerja guru.

Copyright (c) 2021 The Authors. This is an open access article under the CC BY-SA 4.0 license (https://creativecommons.org/licenses/by-sa/4.0/) 


\section{PENDAHULUAN}

Organisasi adalah proses penentuan dan pengelompokan pekerjaan yang akan dikerjakan, menetapkan dan melimpahkan wewenang dan tanggunga jawab dengan maksud untuk memungkinkan orang-orang yang bekerja sama secara efektif dalam mencapai tujuan (Allen dalam Dwiayuni, 2019). Untuk mencapai tujuan diperlukan adanya komunikasi yang baik sehingga apa yang disampaikan dapat dimengerti. Mustawan (2019) menyampaikan bahwa seorang pakar komunikasi menyimpulkan bahwa sekitar 75\% - 90\% waktu kerjasama digunakan pimpinan dan manajer untuk berkomunikasi. Jika dua orang atau lebih bekerja sama, maka diperlukan komunikasi intensif antara para pihak. Semakin baik komunikasi seseorang, maka akan semakin baik pula kualitas kerja sama yang dilaksanakan. Komunikasi yang efektif menuntut rasa saling menghormati, percaya, terbuka dan tanggung jawab. Kepala sekolah sebagai pemimpin atau manajer menyampaikan semua fungsi manajemen ini melalui komunikasi intensif, efektif dan efisien.

Seorang kepala sekolah harus dapat merencanakan, mengorganisasikan, melaksankan dan mengontrol organisasinya dengan menggunakan komunikasi yang baik. Kemampuan berkomunikasi yang baik dan efektif sangat dibutuhkan agar pesanya itu dapat dimengerti, diterima dan bahkan dilakukan oleh komunikan (Suherman, 2016). Proses komunikasi akan efektif apabila komunikator melakukan perananya, sehingga terjadinya suatu proses komunikasi yang baik dan sesuai dengan harapan, di mana gagasan-gagasan atau ide dibahas dalam suatu musyawarah antara komunikator dengan komunikan, dan terjadi pemahaman tentang informasi atau segala sesuatu hal menjadi pokok dari pembahasan untuk mengarah pada kesepakatan dan kesatuan dalam pendapat (Bahrozi, 2015). Upaya tersebut perlu diimbangi dengan kemampuan kepala sekolah dalam membangun komunikasi yang baik terhadap pihak terkait baik internal maupun eksternal (Dwiayuni, 2019). Pihak internal meliputi pendidik dan tenaga kependidikan, komite sekolah dan peserta didik. Sedangkan pihak eksternal yaitu masyarakat terutama masyarakat sekitar sekolah dan lembaga pendidikan lainnya. 
Keberhasilan kepala sekolah dalam menjalankan tugasnya akan dipengaruhi oleh kontribusi pihak lain. Dalam artian, kinerja pimpinan akan dipengaruhi oleh kinerja individu, jika kinerja individu baik akan mempengaruhi kinerja pimpinan dan kinerja organisasi (Rahmat \& Kadir, 2016). Salah satu aspek kinerja yang mempengaruhi keberhasilan tersebut adalah kinerja guru. Kinerja dipahami sebagai kompetensi seseorang dalam melakukan sesuatu dengan keahlian tertentu. Sebagai seorang pendidik, guru dituntut untuk mempunyai kinerja yang baik untuk mencapai program yang yang diwujudkan (Nugroho, 2020).

Pemerintah melalui Undang-Undang No. 14 Tahun 2005 tentang guru dan dosen menyebutkan bahwa kompetensi guru terdiri dari kompetensi paedagogik, kepribadian, sosial, dan profesional. Keempat kompetensi tersebut harus dipahami dan dikembangkan guru sehingga menghasilkan kinerja yang diharapkan. Aspek-aspek yang dapat dinilai dari kinerja seorang guru dalam suatu organisasi dikelompokkan menjadi beberapa bagian, yaitu: a) Kemampuan teknik, b) Kemampuan konseptual, dan c) Kemampuan hubungan interpersonal (Syahri, 2016).

Pada kenyataannya tidak semua guru memiliki kinerja yang baik. Masih banyak permasalahan yang dihadapi oleh kepala sekolah terkait kinerja guru, diantaranya: 1) tidak menyusun perencanaan pembelajaran, 2) meninggalkan jam mengajar sebelum waktunya habis, 3) malas membimbing siswa, 4) malas bekerja, 5) banyak keluhan guru, 6) bersedia bekerja kalau ada upahnya, 7) rendahnya prestasi kerja, 8) rendahnya motivasi diri, 9) rendahnya kualitas pengajaran, 10) indisipliner, dan gejala negatif lainnya.

Salah saatu penyebab terjadinya permasalahan diatas adalah rendahnya intensitas komunikasi yang dibangun oleh kepala sekolah. Oleh karena itu dalam komunikasi perlu diperhatikan mengenai unsur-unsur yang berkaitan dengan proses komunikasi, baik itu oleh komunikator maupun oleh komunikan, dan juga bahwa komunikator harus memahami dari tujuan komunikasi. Beberapa permasalahan terkait komunikasi kepala sekolah sebagai berikut: 1) sering terjadinya kesalahpahaman antar individu, hal ini disebabkan oleh penerimaan informasi yang kurang utuh sehingga seringkali menimbulkan kesalahpahaman, 2) kurangnya intensitas komunikasi baik 
dalam bentuk musyawarah antara unsur kepala sekolah, wakil, pendidik, peserta didik dan masyarakat yang membuat informasi diterima secara tidak utuh dan belum dipahami secara keseluruhan.

Dari latar belakang di atas penulis ingin mengungkap hubungan antara kemampuan komunikasi kepala sekolah terhadap peningkatan kinerja guru. Penelitian ini bertujuan untuk mengetahui pentingnya kepala sekolah memiliki keterampilan berkomunikasi dalam mengelola lembaga, khususnya pada peningkatan kinerja guru.

\section{METODE}

Penelitian ini merupakan penelitian kualitatif dengan teknik analisis deskriptif dengan kajian kepustakaan (library research) dimana penelitian ini berusaha menggambarkan fenomena-fenomena yang ada, yang berlangsung saat ini atau saat yang lampau. Artikel ini menyoroti kemampuan komunikasi kepala sekolah terhadap pengaruhnya dalam meningkatkan motivasi dan kinerja guru.

\section{HASIL DAN PEMBAHASAN.}

Menurut penelitian Fatimah et al. (2015) komunikasi kepala sekolah sangat dibutuhkan untuk meningkatkan profesionalitas. Bentuk komunikasi tersebut dapat berupa penyampaian lisan (memanggilan dan teguran langsung maupun secara tertulis (surat peringatan). Selain itu bentuk komunikasi kepala sekolah dalam juga memilki peran penting dalam meningkatkan disiplin guru, yang ditindaklanjuti dengan memberikan contoh hadir ke sekolah tepat waktu dan pulang paling akhir. Selain itu komunikasi berkontribusi positif terhadap kepuasan kerja dan capaian hasil kerja, kualitas dan kuantitas komunikasi berhubungan kuat dengan kinerja organisasi, kepuasan komunikasi akan menambah positif iklim organisasi (Samto \& Wahyudi, 2018).

Kepala Sekolah berperan sebagai komunikator atau inisiator ide dalam sebuah dialog sekaligus merupakan pihak yang mendengarkan (dalam umpan balik dialog) sehingga ia sekaligus menjadi komunikan (Prananosa et al., 2018). Menurut Mustawan (2019) terdapat pengelolaan komunikasi vertikal dan horisontal oleh kepala sekolah dalam melaksanakan koordinasi tugas, yaitu dengan mendengarkan, memfasilitasi, menanya, menggunakan pertimbangan, dan mengarahkan dengan dewan guru atau 
komite sekolah. Tingkat kemampuan berkomunikasi yang baik dalam melaksanakan tugas sehari-hari, motivasi guru yang tinggi dalam bekerja dan loyalitas terhadap tugastugas pekerjaan sebagai guru tentu akan berpengaruh terhadap kinerja guru (Wibowo, 2013). Kepala Sekolah harus mempunyai kepribadian dan kemampuan serta keterampilan-keterampilan untuk memimpin sebuah lembaga pendidikan (Juwaeni, 2012). Dalam perannya sebagai seorang pemimpin, kepala sekolah harus dapat memperhatikan kebutuhan dan perasaan orang-orang yang bekerja sehingga kinerja guru selalu terjaga.

Terdapat beberapa hal yang harus diperhatikan terkait proses komunikasi khususnya komunikasi interpersonal yaitu: 1) proses komunikasi interpersonal dilaksanakan untuk membentuk sikap terbuka, (2) komunikasi interpersonal bertujuan menguatkan sikap kekeluargaan, 3) media dalam komunikasi interpersonal sangat beragam dan variatif, seperti group wa dan papan pengumuman 4) faktor yang dapat menghambat yaitu mindset dan faktor usia guru yang berbeda 5) kelancaran komunikasi interpersonal didukung dengan adanya sikap terbuka dan komitmen guru untuk berubah dan berkembang 6) komunikasi interpersonal kepala sekolah dalam perspektif manajemen perubahan dengan pendekatan persuasif, dialogis, dan pemberian motivasi (Dwiayuni, 2019). Apabila faktor-faktor tersebut diperhatikan akan berpengaruh pada peningkatan keterampilan komunikasi kepala sekolah yang berimplikasi pada peningkatan kinerja guru.

Komunikasi di sekolah memegang peranan penting diantaranya: (1) Menghubungkan Arus Informasi, Arus informasi yang ada di dalam sekolah bisa dihubungkan dengan baik melalui proses komunikasi. Tanpa adanya komunikasi, proses pembelajaran dalam sekolah pun tidak mungkin bisa terjadi sebab interaksi antara guru dengan murid pun sudah pasti melibatkan sebuah proses komunikasi yang ada di dalamnya. (2) Membantu Tercapainya Tujuan Umum dari Manajemen Sekolah, Manajemen sekolah biasanya memiliki tujuan umum yang tertuang di dalam visi dan misi organisasi masing-masing. Komunikasi akan membantu pencapaian tujuan tersebut karena melalui proses komunikasi itulah visi misi bisa dijabarkan dan disosialisasikan kepada setiap pihak yang terlibat dalam manajemen sekolah. (3) 
Menyelesaikan Masalah Akademik dalam Sekolah, berbagai permasalahan akademik bisa diidentifikasi menggunakan komunikasi yang ada dalam sekolah. Ini akan membantu proses penyelesaian di dalamnya pun cukup terbantu menggunakan proses komunikasi. Tanpa adanya komunikasi, mungkin masalah akademik bisa menjadi lebih berkembang tanpa solusi. (4) Memuat Informasi Pendidikan Terbaru dalam Sekolah. (5) Keilmuan pasti akan selalu berkembang, inilah yang menjadi dasar pentingnya komunikasi dalam manajemen sekolah selanjutnya yaitu tentang pembaruan informasi pendidikan dalam sekolah. Komunikasi akan membantu sosialisasi dari program kurikulum tertentu yang bisa diterapkan oleh sekolah. (6) Menyusun Strategi Pembelajaran Bermutu strategi pembelajaran bermutu juga bisa terwujud dengan adanya komunikasi. (7) Komunikasi akan menghubungkan setiap unsur akademik yang kemudian bisa membuat strategi komunikasi efektif dalam pembelajaran yang dirasa lebih sesuai dan juga berguna bagi setiap pihak. (8) Memberikan Kebebasan Berekspresi. (9) Adanya kesempatan dalam mengungkapkan pendapat, menjadi salah satu fungsi dalam memberikan wadah kebebasan berekspresi dalam manajemen sekolah. Komunikasi memungkinkan hal ini sehingga dinamika dalam amanejemen sekolah pun bisa mulai terlihat. (10) Menjembatani Hubungan Sekolah dan Orang Tua Siswa, (11) Hubungan antara sekolah dengan orang tua siswa juga merupakan hal yang tidak boleh dilupakan dalam manajemen sekolah. Komunikasi menjadi jembatan yang baik sebagai penghubung kedua komponen ini sehingga terjadi proses pembelajaran yang baik bagi peserta didik. Tahap-tahap komunikasi akan tercipta dengan baik. (12) Menciptakan Iklim Edukatif yang Baik, Terakhir, iklim edukatif yang baik bisa terwujud dengan adanya proses komunikasi yang ada di dalam manajemen sekolah. Iklim edukatif ini membuat setiap hal menjadi saling terhubung dan konteks pendidikan yang ada di dalamnya menjadi benar-benar terasa.

Demikian pentingnya komunikasi di dalam sistem pendidikan, sehingga memperhatikan fungsi-fungsi dari pendidikan tersebut memang menjadi sebuah hal yang cukup berguna bagi kita. Kita dapat mempelajari pentingnya komunikasi dalam manajemen sekolah ini sehingga konsep komunikasi pendidikan juga menjadi wajib untuk kita ketahui. Secara konseptual, proses komunikasi berawal dari pemikiran, 
gasasan atau informasi dalam bentuk pesan yang akan disampaikan kepada orang lain melalui media tertentu dalam bentuk tatap muka, tulisan, media cetak maupun media oniline (Sutapa, 2006). Pesan tersebut kemudian ditangkap penerima untuk menguraikan pesan dalam lambang yang sama, dan kemudian ada umpan balik kepada komunikator kalau diperlukan. Umpan balik dimaksudkan untuk mengurangi penyimpangan (distorsi) antara pesan yang dimaksud dengan pesan yang diterima

Menurut Kohler dalam Fatimah et al. (2015) menyatakan bahwa komunikasi yang efektif adalah penting bagi perjalanan organisasi dalam mencapai tujuan. Oleh karena itu, para pemimpin organisasi dan para komunikator dalam organisasi perlu memahami dan menyempurnakan kemampuan komunikasi mereka. Dari pendapat ahli tersebut dapat disimpulkan komunikasi merupakan proses penyampaian informasi dari komunikator kepada komunikan untuk mencapai tujuan tertentu.

Unsur - unsur yang ada dalam proses komunikasi menurut Oteng Sutrisna dalam Bahrozi (2015) adalah: 1) harus ada suatu sumber, yaitu seorang komunikator yang mempunyai sejumlah kebutuhan, ide atau infromasi untuk diberikan, 2) harus ada suatu maksud yang hendak dicapai, 3) pesan dapat berupa fakta, perasaan, atau ide yang dimaksud untuk membangkitkan respon dari pendengar, 4) harus ada saluran yang menghubungkan sumber berita dengan penerima berita, 5) harus ada penerima berita, 6) harus ada umpan balik atau respon dipihak penerima berita. Umpan balik memungkinkan sumber berita untuk mengetahui apakah berita itu telah diterima dan dinterprestasikan dengan betul atau tidak. Proses komunikasi akan berjalan dengan baik dan efektif jika ide, gagasan dan informasi dimiliki secara bersama-sama oleh manusia yang terlibat dalam perilaku komunikasi. Begitu juga dengan komunikasi instruksional. Materi pelajaran akan dicerna dengan baik, jika materi yang disampaikan dapat dimaknai sama oleh peserta didik sebagaimana yang dimaksudkan oleh pendidik.

Menurut Hendra \& Musliadi (2019) terdapat tiga prinsip komunikasi dalam Alquran yaitu:

Edusaintek: Jurnal Pendidikan, Sains dan Teknologi Vol. 8 (1) 2021 | 7 
1. Qaulan Maysuran (perkataan yang mudah dan pantas), lebih menekankan kepada etika dan pesan yang disampaikan komunikator kepada komunikan. Seorang komunikator dalam berkomunikasi dituntut untuk bisa menyesuaikan dirinya dengan keadaan komunikan dan komunikator harus bisa menyampaikan pesan yang bisa dimengerti komunikan, agar komunikan faham pesan yang disampaikan, yaitu pesan yang mudah dan pantas.

2. Qaulan Ma'rufan (perkataan yang baik) lebih menekankan kepada etika komunikator dalam menyampaikan pesan kepada komunikan, agar komunikan mengerti dan tidak berfikiran negatif pesan yang disampaikan komunikator.

3. Qaulan Balighan (perkataan yang efektif), lebih menekankan kepada pesan yang disampaikan komunikator. Karena dalam konteks ini seorang komunikator berkomunikasi dengan komunikan yang keras hati atau yang susah mengerti dari pesan yang disampaikan atau juga komunikan yang munafik. Di sini seorang komunikator harus bisa menyampaikan pesan yang membekas dihati komunikan dan nasehat yang bisa membuat hati komunikan yang keras bisa melunak, pesan yang disampaikan juga bisa membuat efek yang baik dari proses komunikasi yang terjadi.

\section{SIMPULAN}

Dari hasil penelitian yang sudah dilakukan oleh peneliti diatas maka peneliti menyimpulkan bahwa kepala sekolah harus memiliki keterampilan 1) seorang kepala sekolah harus memiliki keahlian melakukan komunikasi baik secara lisan maupun tulisan. 2) Kepala sekolah harus mengelola komunikasi vertical, horosontal dan diamental kepada sekolah dalam melaksanakan koordinasi tugas, yaitu dengan mendengarkan, memfasilitasi, menanya, menggunakan pertimbangam, dan mengarahkan dengan dewan guru atau komite sekolah supaya sekolah mencapai tujuan yang telah ditetapkan. Sehingga semua kompetensi tersebut dapat mempengaruhi peningkatan kinerja guru di sekolah untuk mencapai tujuan pendidikan dan pembelajaran.

Edusaintek: Jurnal Pendidikan, Sains dan Teknologi Vol. 8 (1) 2021 | 8 


\section{DAFTAR RUJUKAN}

Bahrozi, I. (2015). Komunikasi dalam Manajemen Pendidikan. Jurnal Fikroh, Vol. 8(02), $105-118$.

Dwiayuni, M. A. (2019). Keterampilan Komunikasi Interpersonal Kepala Sekolah dalam Perspektif Manajemen Perubahan. Journal2.Um.Ac.Id, 4(2), 55-66. Retrieved from http://journal2.um.ac.id/index.php/jktpk/article/view/10792

Fatimah, Djailani, \& Khairuddin. (2015). Komunikasi Kepala Sekolah Dalam Meningkatkan Kinerja Guru Pada Sma Negeri 1 Geumpang Kabupaten Pidie. Jurnal Administrasi Pendidikan : Program Pascasarjana Unsyiah, 3(4), 149-159.

Hendra, T., \& Musliadi, P. (2019). Prinsip Dan Unsur-Unsur Komunikasi Dalam Prespektif Al -Quran. Wardah, 20(2), 12-31. https://doi.org/10.19109/wardah.v20i2.4546

Juwaeni, H. (2012). ANALISIS FAKTOR KINERJA GURU DALAM Pendahuluan Metode Penelitian.

Mustawan, M. D. (2019). Pengaruh Keterampilan Komunikasi Kepala Sekolah Terhadap Kinerja Guru Di Sekolah Dasar Negeri Lisanpuro 2 Kota Malang. Widya Aksara, 24(1), $1-6$.

Nugroho, S. (2020). Kontribusi komunikasi dan keterampilan manajemen konflik kepala sekolah terhadap kinerja guru. Jurnal Pembangunan Pendidikan: Fondasi Dan Aplikasi, 7(1), 17-25. https://doi.org/10.21831/jppfa.v7i1.24774

Prananosa, A. G., Putra, M. R. E., Yuneti, A., \& Alliyah, R. R. (2018). PENGARUH GAYA KEPEMIMPINAN DAN KETERAMPILAN BERKOMUNIKASI KEPALA SEKOLAH TERHADAP KINERJA GURU. 1, 63-74.

https://doi.org/https://doi.org/10.31539/alignment.v1i2.405

Rahmat, A., \& Kadir, S. (2016). Manajemen Kepemimpinan Dan Kemampuan Berkomunikasi Kepala Sekolah Pada Kinerja Pendidik. Jurnal Komunikasi Untar, 8(1), $1-11$.

Samto, S., \& Wahyudi, W. (2018). Pengaruh Kemampuan Komunikasi Kepala Sekolah Dan Budaya Organisasi Terhadap Prestasi Kerja Guru Smk. Jurnal Pendidikan Dan Pembelajaran Khatulistiwa, 8(10).

Suherman, A. (2016). Analisis Penganggaran Pendidikan Dan Keterampilan Komunikasi Kepala Sekolah Terhadap Kepuasan Kerja Guru Smkn Kabupaten Ciamis. Jurnal Ilmiah Edukasi, 335-342.

Sutapa, M. (2006). Membangun Komunikasi Efektif Di Sekolah. Jurnal Manajemen 
Pendidikan, 2(2), 69-76.

Syahri, P. (2016). IMPLEMENTASI KOMUNIKASI KEPALA SEKOLAH UNTUK MENINGKATKAN KINERJA GURU DI MTS DARUL ULUM BUDI AGUNG KECAMATAN MEDAN MARELAN. Universitas Islam Negeri Sumatera Utara Medan.

Wibowo, B. K. (2013). PENGARUH KOMUNIKASI INTERNAL, MOTIVASI KERJA, DAN LOYALITAS TERHADAP KINERJA GURU SEKOLAH MENENGAH KEJURUAN NEGERI RUMPUN BISNIS SEKOTA SEMARANG. JURNAL STIE SEMARANG, 5(2), 36-47. 